\title{
Introduction to Symposium on International and Comparative Employment Relations: National Regulation, Global Changes
}

\author{
Victor G. Devinatz ${ }^{1}$
}

Published online: 23 June 2017

(C) Springer Science+Business Media, LLC 2017

In this issue's Perspectives section, I am most pleased to present the first part of a symposium on the recently-published book, International and Comparative Employment Relations: National Regulation, Global Changes (6th Edition), edited by Gregory J. Bamber, Russell D. Lansbury, Nick Wailes, and Chris F. Wright (Allen \& Unwin, 2015). In this important volume, a number of international experts in industrial relations and employment relations examine employment relations in 12 major countries throughout the world with the editors providing introductory and concluding chapters discussing their comparative approach to employment relations encompassing the globe.

This symposium consists of four essays written by five scholars who are experts in comparative employment relations. In the first article entitled, "International and Comparative Employment Relations: Assessing the Global, National and Local Level Contributions to the Field of CER," Dr. Mathieu Dupuis, a postdoctoral researcher and visiting fellow at the Cornell University ILR School, argues that international and comparative employment relations must also consider the global level's impact (which includes the rise of finance, the increasing significance of multinational corporations, and trade liberalization) and how local actors use various strategies and different kinds of power to navigate through these factors while affecting workplace outcomes. In the second piece entitled, "Beyond Varieties of Capitalism: Implications of Global Political Changes and the Emerging Shared Economy for Comparative and International Employment Relations," Dr. Teresa Shuk-ching Poon, Associate Professor of the Lee Shau Kee School of Business and Administration at The Open University of Hong Kong, and Dr. Catherine W. Ng, Senior Teaching Fellow in the Department of Management \& Marketing at the Hong Kong Polytechnic University, provide a detailed critique of the Varieties of Capitalism framework utilized by the volume's authors. In the third essay entitled, “'Employment across Markets or Nations': A Review Paper on

Victor G. Devinatz

vgdevin@ilstu.edu

1 Department of Management \& Quantitative Methods, Illinois State University, Normal, IL 61790-5580, USA 
International and Comparative Employment Relations," Dr. Sek-hong $\mathrm{Ng}$, an Honorary Professor in the School of Business in The University of Hong Kong, raises important issues concerning, for example, governmental regulation and technology, among other issues, in comparative employment relations which are discussed in the volume. Finally, the fourth review article entitled, "A Short Essay on International and Comparative Employment Relations," by Dr. Ngan Collins, Senior Lecturer in the School of Management, RMIT University, is the briefest essay in the symposium which summarizes the book's major strengths for potential readers.

The second part of this symposium, to be published in the December 2017 issue, will contain an article by Gregory Bamber, one of the book's co-authors, in which he offers additional reflections on his ideas presented in International and Comparative Employment Relations.

If any of the readers of this symposium are interested in commenting on these four essays in the journal's pages, please do not hesitate to contact me. Other symposiums on important employment relations topics are planned for future issues of the Employee Responsibilities and Rights Journal. If any of the journal's readers have suggestions for symposiums on specific topics, please do not hesitate to contact me. I hope that you enjoy this symposium and find it most illuminating. 